Covered in: ERIH PLUS, HeinOnline, CEEOL, Index Copernicus, CrossRef, CrossCheck, J-GATE, Google Scholar, Ideas RePeC, Econpapers, Socionet, KVK, WorldCat.

2020, Volume 8, Issue 1, pages: 85-93 | doi: 10.18662/lumenlaw/8.1/39

\section{Review of the} volume Valori religioase protejate prin norme juridice [Religious values protected by legal norms], author: Mihai Iulian Necula, Lumen Publishing House, 2020

\section{Antonio SANDU1}

${ }^{1}$ Faculty of Law and Administrative Sciences, Stefan cel Mare University of Suceava, Romania, antonio1907@yahoo.com
Abstract: The worth of values, more precisely those protected by legal norms, is approached by Mihai Iulian Necula in the volume Religious values protected by legal norms, a book published in 2020 by Lumen Publishing House, in Iasi, Romania. The volume represents the doctoral thesis in the field of law of Mr. Mihai Iulian Necula and is a study of novelty in the Romanian editorial and cultural space when we discuss in legal terms about the defense of religious values. Of course, values must be defended, and the legal instrument is one of the most important such tools to promote, but especially to protect a number of recognized values, such as religious values.

Keywords: Religious values, secular values, legal protection of ethical values, Mibai Iulian Necula

How to cite: Sandu, A. (2020). Review of the volume Valori religioase protejate prin norme juridice [Religious values protected by legal norms], author: Mihai Iulian Necula, Lumen Publishing House, 2020. Logos Universality Mentality Education Novelty: Law, 8(1), 85-93.

doi:10.18662/lumenlaw/8.1/39 
Voi începe prin a discuta ce sunt valorile şi, mai ales, despre ce valori religioase putem vorbi că sunt protejate prin norme juridice. Sigur că valoarea este un concept în primul rând filosofic, axiologic, spiritual, dar destul de puțin discutat în literatura de specialitate. Vorbim de o întreagă ramură a filosofiei, mai exact despre axiologia care este teoria valorilor, dar dacă suntem atenți vom constata că de obicei luăm ca atare ideea de valoare ca fiind ceva valoros şi, ca atare, ceva important. Avem o definiție circulară a ceea ce sunt valorile, pe care le definim ca fiind lucrurile care sunt importante pentru noi, deşi această modalitate de a le defini este un pleonasm. Binele este o valoare morală şi universală, frumosul, adevărul toate acestea sunt valori şi avem valori intrinseci sau extrinseci, adică valori care sunt importante prin ele însele şi valori care sunt importante pentru că duc la realizarea altor valori; de exemplu, vorbim despre binele public ca valoare în politicile publice şi putem vorbi de exemple de echitate, dreptate, egalitate, egalitate de şanse şi aşa mai departe, de tot atâtea valori care vin să permită sau să ducă la înfăptuirea binelui public şi totuşi nu avem o definiție nici unamim acceptată şi nici intrinsecă a acestuia, atunci când vorbim în termeni de valori, pentru că nu avem valori unice.

Dacă binele, frumosul, adevărul sunt astfel de valori care preocupau filosofia în lumea antică, fie ea greacă, romană sau din alte zone unde înțelepciunea a fost o preocupare a umanității, avem în zilele noastre valorile materiale, valorile înavuţirii şi aşa mai departe, care sunt preocupări cotidiene. In cercetările noastre anterioare am considerat că există însă o categorizare care explică sau putem găsi o categorizare care să poată explica mai bine acțiunea socială a valorilor, şi anume clasificarea lor ca valori constitutive şi valori operaționale. Valorile constitutive sunt acele valori care duc la apariția unei instituții, a unei activități, a unei ramuri a vieții umane, fie că vorbim, de exemplu, de înfăptuirea binelui public şi pentru a înfăptui binele public avem instituții politice, sociale, civice, economice şi aşa mai departe, toate acestea au până la urmă ca valoare constitutivă ideea de bine public sau valoarea binelui public, iar pentru înfăptuirea binelui public trebuie să găsim o serie de libertăți economice, sociale, civile, religioase, politice care, împreună, să poată ajuta la înfăptuirea acestui bine public. Şi valorile operaționale, desigur, sunt valori care ghidează modul în care aceste instituții sociale, politice sau civile funcționează. De exemplu, egalitatea de şanse ghidează modul în care în interiorul unei organizații se desfăşoară activitatea şi se urmăreste îndeplinirea scopurilor organizației, întrucât scopurile aceasteia sunt, până la urmă, legate de valorile constitutive ale acestei organizații. Asistența socială ca practică şi psihologia au o serie de valori constitutive care au făcut necesară apariția ideii de asistență socială, a 
ideii de sănătate publică, vorbim de egalitate de tratament, vorbim de nondiscriminare, toate acestea fiind valori operaţionale pentru aceste instituții, în timp ce binele public sau dreptatea pot fi considerate valori constitutive care au generat întregi sisteme sociale sau sisteme de instituții sociale.

Şi unul dintre cele mai importante sisteme de instituţii sociale sunt instituțiile cu caracter religios, iar aici ajungem la volumul lui Iulian Necula „Valori religioase protejate prin norme juridice” (Necula, 2020), care pare să ne spună sau să ne sugereze că sfințenia este valoarea centrală a instituțiilor religioase, fie că acestea sunt instituții formale, culte religioase, instituții de cult, biserici, mânăstiri, fie că vorbim de instituții non-formale, în sensul în care vorbim de rugăciune, unde instituția înseamnă o serie de norme, de reguli care împreună fac ca o anumită activitate, o anumită acțiune umană să fie eficientă. Şi atunci valorile spirituale, valorile religioase - cel puțin aşa cum îi apar lui Iulian Necula şi aşa cum am rezonat cu lucrarea sa - au ca valoarea centrală pentru toate instituțiile religioase o valoare constitutive care este sființenia. $\mathrm{Cu}$ alte cuvinte, nu Dumnezeu, aşa cum ar crede mulți, este în centrul sau ar trebui să fie în centrul religiei, pentru că atunci când îl pui pe Dumnezeu în centrul religiei ca valoare, deşi Dumnezeu este o valoare infinită, Dumnezeu ne înfăptuieşte pe noi, dar noi trebuie să înfăptuim starea de sființenie, pentru că este modul în care noi ne raportăm la Dumnezeu şi pentru a fi în Dumnezeu, valoare noastră este sfințenia, iar de aici extragem ideea că aceasta este o valoare constitutivă a religiosului, a spiritualului.

Dacă ne-am propune ca valoare pentru religie, pentru spiritualitate orice altă valoare în afară de sfințenie, în afară de îndumnezeire, acestea ar fi valori operaționale care ne-ar spune cum să ne întreptăm către Dumnezeu, pentru că sființenia înseamnă, pâna la urmă, a ne întrepta continuu către Dumnezeu, a trăi în Dumnezeu, a fi în Dumnezeu. Şi abordarea deosebit de atractivă propusă de Iulian Necula este apărarea, protejarea acestor valori tocmai prin norme juridice. Desigur că atunci când vorbim de valoarea central a sfințeniei ne întrebăm ce fel de norme juridice o pot viza, altele decât cele exprimate, să spunem, de Moise sau de Dumnezeu prin Moise în Vechiul Testament - cele 10 porunci - şi modul în care acestea se raportează la sistemele de drept din Antichitate şi până în present, sau la ceea ce se numeşte cu adevărat lege, legea cea nouă, o nouă lege pe care Iisus Hristos ne-o dă. Acestea sunt până la urmă legi, dar sunt legi care nu fac parte din coduri de natură juridică pentru că, oricât de mult ne-am duce către această lege universală, supremă, spirituală dată de Dumnezeu însuşi, noi nu am putea decât să înfăptuim partial această valoare a sfințeniei, pentru că această valoare a sfințeniei este apărată de aceste porunci, între care cea mai importantă este să îl iubeşti pe Dumnezeu. Dar a-L iubi pe Dumnezeu fără a 
manifesta iubire față de aproapele tău, faţă de toți cei cu care interacționezi sau cei care aparent doar îți sunt departe - pentru că există ființe pe care nu le vom vedea niciodată şi pe care atunci când avamsăm pe calea spirituală începem să ne dăm seama că le iubim oriunde ar fi, chiar dacă au alte religii decât noi şi alte tradiții - nu înseamnă a respecta porunca iubirii, întrucât aceasta se referă şi la ei, ceea ce adduce în prim plan discuția cu privire la responsabilitatea față de non-prezență, față de cei pe care nu-i vedem. Această responsabilitate supremă provine, desigur, din iubire şi iată cum, de fapt, aceste două porunci înfăptuiesc valoarea sfințeniei.

Totuşi, cum poate fi apărată această valoare prin norme juridice? În primul rând, apărând libertatea de cult. Şi o importantă preocupare a autorului Iulian Necula este cu privire la apărarea libertății religioase, de exemplu protecția libertăţii religioase în raport cu alte drepturi şi libertăţi universal, în raport cu libertatea de exprimare, iar aici autorul adduce în discuție praxisul juridic, fiind făcute trimiteri la comisia de la Veneţia şi activitatea acesteia, la protecția penală a libertății credințelor religioase, la valori care sunt consacrate de Constituția României, la concursul de valori şi de libertăți dintre cele religioase şi alte instituții juridice care sunt cuprinse în dreptul penal şi pot fi puse în raport cu valorile creştine. Înainte însă de a analiza aceste valori şi modul în care acestea sunt transpuse pentru că a înfăptui o valoare înseamnă a da curs la o acțiune socială, iar acea acțiune socială trebuie ordonată, trebuie pusă în acțiune, pentru că vorbim de o acțiune comunicativă în sens habermasian, care urmăreşte obținerea unui consens, şi de o acțiune socială, care dincolo de consens urmăreste o eficiență imediată.

Prin urmare, pentru a putea să vorbim ce adevărat de libertate religioasă, avem nevoie de o serie de norme cu caracter juridic care, de exemplu, să interzică tortura, care să interzică o serie de limitări ale drepturilor religioase, care să permită ca acestea să fie mai ales afirmative, cu privire la exercitarea dreptului de întrunire în cadrul cultelor religioase, de manifestare a credinței religioase, de exprimare a acestor credințe. Cartea este deosebit de actuală, apărând în perioada pandemiei de Coronavirus, deşi a fost scrisă cu câțiva ani înainte, dar a apărut, nu întâmplător, tocmai acum când o serie de libertăţi religioase au fost puse temporar în paranteză, sub semnul întrebării, o altă valoare decât libertatea religioasă trecând înaintea acesteia, anume sănătatea publică. Acum, în numele sănătății publice, exercitarea în fapt a unor valori cum ar fi dreptul de întâlnire, dreptul de exprimare a credinței, dreptul de participare în comun la ritualuri religioase au fost amânate, inclusiv într-o astfel de perioadă, de o însemnătate deosebită pentru adepții anumitor culte. Sănătatea publică este o valoare care 
în prezent trece înaintea valorilor spirituale pentru că, pornind de la ideea că viaţa este importantă, pentru ca indivizii să îşi poată exercita inclusiv libertăţile religioase trebuie să existe şi să trăiască şi să fi sănătoşi.

$\mathrm{Cu}$ toate acestea, unii dintre adepții cultelor religioase consideră că valoarea religioasă este pentru ei prioritară faţă de a sănătăţii publice, fiind mai important să îşi poată exprima credința decât să apere sănătatea publică. Este salutar din punctul meu de vedere opțiunea prin care majoritatea cultelor religioase au aderat la aceste norme referitoare la sănătatea publică. Până la urmă această aderare este exprimată în porunca divină şi este, dacă suntem atenți, o exercitare a acestei porunci de a-ți iubi aproapele, deoarece atunci când îți iubeşti aproapele îți doreşti ca acesta să trăiască şi să fie sănătos, iar atunci instituția Bisericii nu ar putea să pretindă punerea în pericol a vieții pentru ca indivizii să poată participa la ritual. Unii însă au considerat că punerea în pericol a vieții poate fi o cale spre avansarea spirituală; martirajul este un exemplu în acest sens, în care valorile spirituale sunt plasate mult deasupra valorilor mundane, inclusiv a apărării propriei vieți, a propriei sănătăți. Cu toate acestea, martirajul ar trebui să fie o situație extremă de afirmare a libertăţii religioase atunci când forțe opresive o limitează, nu pentru că acestea au o justificare temporară, ci pentru că propriile lor valori sunt impuse peste ale martirului şi atunci a înfăptui valoarea cere uneori fapte de martiraj.

Revenim la ideile pe care le exprimă Iulian Necula şi anume faptul că întâi trebuie să vedem cum s-au poziționat de-a lungul timpului valorile religioase în sfera actelor normative, iar autorul începe cu libertatea religioasă în Antichitate, raportul dintre valorile juridice şi cele religioase în Antichitate constituind o parte a capitolului al II-lea, unde este prezentat istoricul interferenței dintre valorile juridice şi cele religioase când sunt aduse în discuție situaţia Greciei, a Daciei, a Imperiului Bizantin, dar şi în statul iudaic, care erau un stat teocratic, apoi în Evul Mediu, în Ţările Române şi aşa mai departe, dar autorul trece şi către spaţiul apusean, unde vorbeşte despre existenţa statului Vatican, despre statele teocratice şi formele de guvernare bazate pe valori religioase. Desigur că o astfel de formă de existență a statului, cum este Vaticanul, cristalizată în scopul înfăptuirii valorilor religioase, pare că apără mai degrabă valorile religioase formale decât pe cele perene, pentru că este foarte greu ca prin intermediul unui stat teocratic să aperi sfințenia. Putem da exemple şi de alte state, care se doresc a fi teocratice, dar de fapt sunt mai degrabă teroriste, cum ar fi statele islamice extremiste care, în numele apărării unor valori religioase, distrug tot ceea ce pare a fi potrivnic propriilor valori, sens în care apare nevoia ca ideea de stat teocratic să trebui să fie pusă doar în legătură cu sfințenia. 
Platon vorbea despre filososul rege, despre cel care se apropie de înțelepciune şi ar trebui să fie cel care guvernează societatea, iar cetatea „De civitas Dei" de care vorbeşte Augustin necesită o îndrumare spirituală a unor lideri care să aibă cu adevărat înţelepciune, dar şi o anumită participare la sființenie. Şi poate că nu întâmplător vorbim despre un stat laic atunci când un stat teocratic eşuează sau este ineficient. A fi transformată spiritualitatea în instrument de cucerire politică este la îndemâna multor autoritari, aşa cum extrema laică poate duce la intoleranță de natură religioasă, cum a fost situația în statele comuniste, când prigoana religioasă a oricărei religii în numele unui ateism ştiinţific a condus către cealaltă extremă, a respingerii religiozităţii şi a credinței. Până la urmă, apărarea valorilor credinței reprezintă apărarea unor valori individuale, personale şi nu impunerea unei credințe, a unei dogme, a unei doctrine, ci impunerea libertății în toate formele sale de manifestare.

Iulian Necula continuă cu o analiză a valorilor religioase care astăzi sunt în continuare apărate prin norme juridice. Vorbim de drepturi cum ar fi dreptul la viaţă şi problematica dezincriminării unor fapte. Eutanasia este un astfel de exemplu, când dreptul la viață şi la a decide cu privire la propria viață vine în contradicție cu comandamentele religioase de a nu atenta la propria viață. Iulian Necula vorbeşte pe larg despre eutanasie şi despre reglementările penale cu privire la aceasta, dar şi de reglementările teologice. De asemenea, autorul abordează tema prostituției, făcând o comparație între situația din Franța, din Italia şi din România, despre adulter, homosexualitate, toate acestea fiind incriminate de valorile religioase, mai ales de valorile specific creştine, dar şi de alte culte religioase. Însă acestea sunt în general considerate valori personale şi atunci statul laic, modern tinde să dezincrimineze o serie de fapte, care sigur rămân în sfera păcatului, dar nu a interdictivului juridic.

Practic, Dumnezeu însuşi nu ne-a limitat - sau interzis - posibilitatea de a păcătui, ci doar ne-a spus că păcatul are un preț. Atunci înseamnă că nu ar trebui să vorbim nici despre o inchiziție publică sau privată care să limiteze păcatul, dar ar trebui să vorbim despre o inchiziție morală, interioară care să ne limiteze păcatul şi apoi, mai mult decât atât, de iubirea transformatoare: dacă sufletul tău crede şi simte că poți să aduci o anumită acțiune ca ofrandă lui Dumnezeu şi o poți face în apropierea ta de Dumnezeu, atunci acela nu este păcat. Totuşi, ar trebui să ne limităm această viziune atunci când vedem că există, spre exemplu, terorişti care îşi dau viaţa pentru un act suicidal, dar eroic în numele religiei. Între luptătorii kamikaze japonezi, care se aruncau cu avionul în port-avioanele americane în numele credinței în împărat şi martirajul primilor creştini e foarte greu să putem 
discerne dacă pornirea sufletească care a condus la act a fost una de factură păcătoasă sau nu, în sensul de realitate a trăirii mistice care duce la sacrificiu. Noi însă înţelegem în martiraj sfințenia şi în terorism cooperarea cu întunericul. Şi atunci ar trebui să intervină legea şi să afirme care valori sunt apărate, pentru că aceste valori aparțin majorităţii, şi care sunt limitate, chiar dacă există o anumită permisivitate, însă că valorile respective sunt apărate.

Dezincriminarea unor fapte care rămân păcate se face în spiritul libertății, atâta vreme cât statul laic nu ar trebui să intervină în viața privată, nici în cea spirituală, religioasă, dar nici în cea socială decât atunci când libertatea personală contravine libertății celorlalți ca pricipiu de drept. Astfel de dezincriminări apără mai puțin valorile religioase, dar apără o serie de valori ca statul de drept, iar statul de drept are ca scop apărarea valorilor personale ale cetăcenilor, aşa cum aceştia le adoptă la un anumit moment în dezvoltarea istoriei.

Desigur că există şi situaţia inversă, în care sunt incriminate fapte relevante în raport cu valorile creştine: de exemplu, incriminarea unor ritualuri de exorcizare şi a circumciziei ritualice, incriminarea unor ritualuri atunci când acestea sunt duse la extrem, atunci când acestea pun în pericol viața unor persoane, sănătatea acestora, cum ar fi practicile care ar cere sacrificii umane. Incriminarea însăşi a unor practici de natură religioasă exprimă, de asemenea, evoluția unei sociețăți şi posibila distanțare a acesteia de valorile spirituale. Ne vorbeşte de asemenea Iulian Necula despre instrumentele juridice care permit păstrarea şi susținerea valorilor religioase, aşa cum ele există la ora actuală în tratatele internaționale, în convențiile internaţionale la care România este parte şi este meritul lui Iulian Necula că ne aduce în atenție aceste abordări strict formal juridice, dar mai ales a practicii juridice cu privire la apărarea valorilor religioase.

Câteva cuvinte despre autorul acestui volum: părintele Mihai Iulian Necula: s-a născut în Piatra-Neamt, în data de 08.01.1976. A absolvit studii medii economice, studii superioare de teologie şi drept, are un masterat în drept european la Centrul de Studii Europene a Universităţii „Al. I. Cuza” din Iaşi şi este doctor în ştiințe juridice din anul 2014, volumul de față fiind rezultatul susținerii tezei de doctorat, sigur un rezultat absolut meritoriu, mai ales atâta vreme cât se preocupă de un domeniu interdisciplinar rar abordat şi continuă să se preocupe de o perspectivă interdisciplinară între studiile religioase şi drept, cu ocazia publicării mai multor articole de specialitate. Din anul 1988 este preot ortodox şi a fost în perioada 2001 - 2015 inspector bisericesc şi consilier economico - financiar în cadrul Arhiepiscopiei Iaşilor. De asemenea, este practician în insolvență din anul 2015. Teza de doctorat originală a fost coordonată de prof. dr. Tudorel Toader, la data aceea 
decanul Facultății de Drept, actualmente rector al Universității Universității „Al. I. Cuza”, care îl apreciază pe Iulian Necula cu aceste cuvinte: „Când teologul şi juristul Mihai - Iulian Necula a fost admis la Şcoala Doctorală a Facultăţii de Drept din cadrul Universităţii „Al. I. Cuza” din Iaşi, am considerat demersul domniei sale drept o provocare ştiințifică. Societatea românească avea pe agenda publică discuții legate de rolul şi locul religiei în contextul democratic, cum ar fi modul în care poate fi integrată în planurile de învăţământ pentru studiile preuniversitare. Dat fiind profilul profesional, i-am propus ca în cadrul studiilor de doctorat să elaboreze o teză prin care să prezinte protecția valorilor religioase prin normele juridice penale. Inițial, nu am avut sentimentul că debordează de entuziasm, ulterior mărturisindu-mi că subiectul îi apare ca fiind extrem de complex. Am fost convins însă, încă de la început, că va reuşi să ducă la bun sfârşit misiunea pe care i-am încredinţat-o.

Lucrarea de faţă este, în primul rând, o invitaţie la colocvialitate, aşa cum se doreşte şi se sugerează chiar prin imaginea de pe prima copertă. Îndemnul la dialog le este adresat teologilor şi juriştilor, dar nu îi omite nici pe filosofi şi politicieni. Bibliografia amplă folosită aduce în prim-plan domenii ale vieții sociale care nu sunt exclusiv ale dreptului sau ale teologiei, ci sunt domenii comune, însă ca urmare a unor evoluții istorice sub imperiul autonomizării, se doresc a fi confiscate de către unul sau de către altul din aceste domenii. Cu riscul sărăcirii de conţinut, astfel lucrarea aduce împreună instituții sociale care sunt cu atât mai complexe cu cât la conturarea lor contribuie dreptul şi teologia, dar şi alte domenii de studii precum: istoria, filosofia, sociologia. Din această perspectivă, considerăm că lucrarea prezintă interes atât pentru jurişti, cât şi pentru teologi, dar şi pentru alte profesii”.

Am incheiat citatul din materialul propus de profesorul Toader Tudorel ca prezentare a volumului de faţă sub forma unui cuvânt înainte pe care domnia sa îl aduce acestei cărți. Sigur că am omis să prezint tocmai această actualitate a cărții din perspectiva pe care profesorul Toader Tudorel a exprimat-o, tocmai pentru a nu mă suprapune cu cuvintele domniei sale, care are cu siguranță mult mai multă înțelegere şi competență pentru a analiza fenomenul socio-juridic din perspectiva dreptului penal, în care este un excelent profesor şi i-a fost un minunat magistru lui Mihai - Iulian Necula. 


\section{Acknowledgement}

O variantă inițială a acestei recenzii a fost prezentată inițial ca recenzie online, sub titlul Sandu, A. (2020, August 17). Valori religioase şi norme juridice [Videoclip YouTube]. https://www.youtube.com/watch?v= ZLh8JUfK8xw\&feature $=$ youtu.be\&fbclid $=$ IwAR3tWoEHb0v58GX5sQ2D PLYMvM vT0cKknwkfiTAJEoNDr TcIPwBANeuYs

\section{References}

Necula, M. I. (2020). Valori religioase protejate prin norme juridice [Religious values protected by legal norms]. Lumen. 